\title{
Impact of Water Management on Growth and Yield of Ahu Rice Varieties of Assam, India
}

\author{
B. Gogoi ${ }^{1 *}$, R.K. Thakuria ${ }^{2}$ and N. Deka ${ }^{1}$ \\ ${ }^{1}$ Krishi Vigyan Kendra, Nagaon, Assam Agricultural University, Assam, India \\ ${ }^{2}$ Assam Agricultural University, Jorhat, Assam, India \\ *Corresponding author
}

\begin{abstract}
A B S T R A C T

\begin{tabular}{|l|}
\hline Ke y w o r d s \\
Ahu rice, Dishang, \\
Luit, Shallow tube \\
well, Water \\
productivity
\end{tabular}

A field study was carried out during early Ahu/Boro season in the year 2016 at Konwargaon village of Morigaon district of Assam funded by AICRP on Water Management under the supervision of Krishi Vigyan Kendra, Morigaon, Assam to evaluate the effectiveness of shallow tube well irrigation with two improved rice varieties (Luit and Dishang) and one traditional variety (Soru Guni) among 15 numbers of farmers covering an area of 2 ha. The growth and yield attributing characters of Dishang varieties were found to be better over the other two tested varieties. The water productivity was recorded highest in Dishang $(5.3 \mathrm{~kg}$ per $\mathrm{mm})$. The highest grain yield was obtained from variety Dishang (5.42 t/ha) followed by Luit $(3.50 \mathrm{t} / \mathrm{ha})$. The maximum net return (Rs. $81300.00 /$ ha) and B:C (3.19) were recorded from Dishang variety when irrigated up to 5 $\mathrm{cm}$ at 3 days after disappearance of ponded water (DADPW). The resultant effect has shown that effective water management practices along with use of suitable variety help in improving the yield per drop of water used and can double the income of farmers.
\end{abstract}

\section{Introduction}

Rice is one of the most important cereal crops in the world, and $90 \%$ of worldwide rice cultivation takes place in Asia (IRRI, 1993). In India it is the most important staple food crop. More than 90 per cent of Assam's population being rice eaters; it is the only staple food crop in Assam of which autumn rice holds significance because of the food security of about 62.6 per cent of marginal farmers. Being the single major source of agricultural GDP, rice also plays a significant role in the state economy Water is a critical component of all crops and due to water scarcity there is a shift towards low water required crops. Under irrigated system water management reckons challenge as water is becoming scarce and precious over time. In Assam rice is grown throughout the year in three distinct seasons viz. winter, autumn and summer, with winter (kharif) rice as the main crop. Of the state's total rice area of 2.5 million ha, summer (boro/early ahu) rice covers about 0.42 million ha (16.9\%) contributing to 23.44 per cent of total rice production with reasonably higher yield (2940 $\mathrm{kg} / \mathrm{ha})$ than winter rice $(2120 \mathrm{~kg} / \mathrm{ha})$. Summer rice has gained importance over the last two decades. Its area increased from only about 
0.15 million ha (1991-92) to about 0.42 million ha (2013-14) because of higher yield, increase in area under irrigation, flood escaping nature and prevalence of lowlands.

Rice is considered as one of the high water consuming crops and also to be one of the major reasons of global warming due to production and emission of methane gas from the puddled soil practised for rice. The prevailing rice production systems require about 1900 to 5000 litres of water to produce $1 \mathrm{~kg}$ of grain. Water availability has been reducing over years and it is expected that by 2030 India will also be in the list of water deficit country with the anticipated per capita availability of the critical limit of 100 cubic metre per annum. It is also expected that by 2025 , about $10 \%$ of irrigated rice will face water scarcity (Bouman et al., 2007). Since summer rice is the most potential one and water has become scarce and precious, it has become important to standardize recommended water saving technology in farmers' field with farmers' participation.

The knowledge of recommended technology and its comparative study along with farmers' own practices of water management will not only generate important feedback for researchers but also help the farmers to enhance their production and productivity of summer rice. It is felt to be necessary to produce more food with less water or per drop more crop especially for rice as it requires large amount of water at its different growth stages (Table 1).

Loss of water in rice field is also a problem due to different climatic factors which cannot be controlled as shown in table 2 and especially so during the dry season (summer). However, intermittent irrigation or alternate wetting and drying, can reduce water loss along with increasing the yield of rice. Keeping in view the importance of potential summer rice and per drop more crop concept, an ORP was conducted to have comparative assessment on the effectiveness of water management rice upto $5 \mathrm{~cm}$ level at 3 days after disappearance of ponded water (DADPW) and farmers' practice of continuous submergence.

\section{Materials and Methods}

During February month of 2016 (early ahu), an ORP on water management in Ahu rice variety viz., Disang, Luit and Soru Guni conducted by AICRP on water management in the farmers' field at two different villages of Morigaon District involving 15 number of farmers under the Supervision of Krishi Vigyan Kendra, Morigaon. A total of 2 ha land area covered in the trial. Farmers were advised to use recommended fertilizers rate of 40:20:20 N: P: K kg/ha with split application of urea, first half as basal and other half at 30 DAT. The irrigation was given at $5 \mathrm{~cm}$ level at 3 days after disappearance of ponded water in the main field. The seed treatment with Carbendazim 50\%WP @ 2.5g per kg of seed was practised before sowing in the nursery bed. The seedlings were uprooted at 12 DAS and root-dip treatment was done with Chloropyriphos 20 EC @ $1 \mathrm{ml}$ per litre before transplanting. The scientists encouraged the farmers to go for cultivation of ahu rice along with irrigation practices and line sowing because there is negligence of cultivation of ahu rice due to shortage of water supply during ahu season and yield is low due to lack of improved varieties, lodging problems, insect-pest damage. However, farmer's agreed to go for all good agricultural practices and on the day of harvesting, one field day was organized to acquaint other farmer's with this technology.

The results obtained were statistically treated with randomized block design to test the validity of the experiment conducted 


\section{Results and Discussion}

The three different varieties were taken for the ORP and the treatment was followed only in Disang and Luit. The local ahu variety (Soru Guni) was kept as check against the HYV maintaining a thin layer of water throughout the whole growing period till the reproductive period was attained. Different characteristics were studied over the growing season as mentioned below. Among these two varieties, Dishang was mostly preferred by farmers over Luit variety due to its good cooking quality as per intrapersonal communication about the two varieties among 100 numbers of farmers. Moreover less infestation of stem borer was recorded with Dishang variety than that of Soru guni and Luit. The percentage of infestation of stem borer was $4.3 \%$ in Dishang and $11.7 \%$ in Luit. Proper control measures were taken for management of pest and diseases.

Characteristics of the variety considered for experiment

\section{Dishang}

It is a short duration direct seeded late sali variety but can be grown as early ahu. The duration of crop is $90-95$ days. This variety is a selection from cross between rice variety
Lachit and Kalinga 3. The grains are medium slender with good cooking quality. This variety is suitable for sowing after recession of flood due to its photo insensitive nature and short duration.

\section{Luit}

It is a semi-dwarf rice variety with medium bold grains and low tillering habit (6-7 EBT/plant). It is a selection from cross between Heera and Annada at Regional Agricultural Research Station, Assam Agricultural University, Titabar, Assam. It is resistant to bacterial leaf blight and leaf blast. It matures in 90-95days in Sali season and 100 days in Ahu season.

\section{Soru guni}

It is a traditional direct seeded $a h u$ rice variety of Assam, suitable for rainfed areas. It is a medium tall variety. This variety is popular in Assam because of its slender and medium bold size grain. The lower leaves are droopy in nature which helps in suppression of weeds while upper leaves are semi erect for enabling more photosynthesis as compared to other traditional $a h u$ varieties. However, the variety has thin stalk with less lodging resistance. It matures in 85-90 days with an average yield of $2.0 \mathrm{t} / \mathrm{ha}$.

Table.1 Water requirement of rice at different growth stages

\begin{tabular}{|l|c|c|}
\hline \multicolumn{1}{|c|}{ Stages of growth } & $\begin{array}{c}\text { Avg. water } \\
\text { requirement }(\mathbf{m m})\end{array}$ & $\begin{array}{c}\text { \% of total water } \\
\text { requirement (approx.) }\end{array}$ \\
\hline Nursery & $50-60$ & 5 \\
\hline Main field preparation & $200-250$ & 20 \\
\hline Planting to Panicle initiation (PI) & $400-550$ & 40 \\
\hline P.I to flowering & $400-450$ & 30 \\
\hline Flowering to maturity & $100-150$ & 5 \\
\hline Total & $\mathbf{1 2 0 0 - 1 4 6 0}$ & $\mathbf{1 0 0 . 0}$ \\
\hline
\end{tabular}


Table.2 Water requirement and losses of water in rice fields

\begin{tabular}{|l|c|c|c|c|}
\hline \multicolumn{1}{|c|}{ Particular } & Clay Loam & Silty Clay & Loam & Sandy Loam \\
\hline Water requirement & 1583 & 1602 & 1995 & 2261 \\
\hline Irrigation & 1125 & 1200 & 1500 & 1775 \\
\hline Runoff & 207 & 191 & 193 & 161 \\
\hline Percolation & $893(56 \%)$ & $870(54 \%)$ & $1187(60 \%)$ & $1515(67 \%)$ \\
\hline Evapotranspiration & $690(44 \%)$ & $732(46 \%)$ & $808(40 \%)$ & $745(33 \%)$ \\
\hline
\end{tabular}

Table.3 Plant parameters of technology studied with the farmer's practice

\begin{tabular}{|l|l|c|c|c|}
\hline Sl no. & \multicolumn{1}{|c|}{ Treatments } & $\begin{array}{c}\text { Average plant } \\
\text { height }\end{array}$ & $\begin{array}{c}\text { Length of panicle } \\
\text { No. of filled grains } \\
\text { per panicle }\end{array}$ \\
\hline 1. & Dishang & 127.64 & 21.24 & 160.64 \\
\hline 2. & Luit & 123.64 & 21.24 & 149.64 \\
\hline 3. & Soru Guni (FP) & 116.64 & 17.85 & 98.44 \\
\hline & CD(0.05) & $\mathbf{4 . 3 8}$ & $\mathbf{1 . 4 1}$ & $\mathbf{6 . 4 4}$ \\
\hline & CV (\%) & $\mathbf{5 . 3 8}$ & $\mathbf{3 . 4 2}$ & $\mathbf{1 0 . 4 8}$ \\
\hline
\end{tabular}

Table.4 Yield attributing characters of technology studied with the farmer's practice

\begin{tabular}{|l|c|c|c|}
\hline \multicolumn{1}{|c|}{ Treatments } & $\begin{array}{c}\text { No. of tillers per } \\
\text { hills }\end{array}$ & $\begin{array}{c}\text { No. of panicles } \\
\text { per plant }\end{array}$ & Yield (t/ha) \\
\hline Dishang & 19.45 & 24.09 & 5.42 \\
\hline Luit & 17.73 & 21.64 & 4.01 \\
\hline Soru Guni (FP) & 10.73 & 12.45 & 2.62 \\
\hline CD(0.05) & $\mathbf{2 . 5 0}$ & $\mathbf{2 . 6 7}$ & $\mathbf{0 . 9 3}$ \\
\hline CV $(\%)$ & $\mathbf{1 3 . 4 4}$ & $\mathbf{1 2 . 6 5}$ & $\mathbf{7 . 3 8}$ \\
\hline
\end{tabular}

Table.5 Economic analysis of the ahu rice cultivation

\begin{tabular}{|l|c|c|c|c|}
\hline \multicolumn{1}{|c|}{ Treatments } & $\begin{array}{c}\text { Total Cost } \\
\text { (Rs./ha) }\end{array}$ & $\begin{array}{c}\text { Gross return } \\
\text { (Rs/ha) }\end{array}$ & $\begin{array}{c}\text { Net return } \\
\text { (Rs/ha) }\end{array}$ & B:C Ratio \\
\hline Dishang & 25500.00 & 104300.00 & 81300.00 & 3.19 \\
\hline Luit & 25500.00 & 83150.00 & 60150.00 & 2.36 \\
\hline Soru Guni (FP) & 26800.00 & 67300.00 & 39300.00 & 1.47 \\
\hline
\end{tabular}

Sale price@ Rs 15 per kg of grains

Luit and Dishang had shown a better plant characters attributable to yield (Table 3 ). The observations like plant height, Length of panicle and No. of filled grains per panicle which was found to be highest in Dishang followed by Luit. The traditional variety Soru guni was observed to be droopy in nature and lodge at the time of maturity. The high yielding varieties remains stout over the growing period and because of this the light interception is more over the traditional variety which is a major reason of higher 
yield over the local or traditional variety. The effects of $5 \mathrm{~cm}$ irrigation after three days after disappearance of ponded water was found to be most effective in both the high yielding ahu varieties. Dishang recorded the highest no. of tillers per hill, no. of panicles per plant and yield as shown in Table 4. In Malaysia, Khairi et al., (2015) conducted an experiment to test the effect of rice plant cultivated under different water regimes. These results suggested that field saturated to $1 \mathrm{~cm}$ flooding water could easily be implemented in rice cultivation by the farmers which might not affect rice production, plant and soil characteristics.

Soil water lower than saturated condition reduces the yield of rice (Tuong and Bouman, 2003). Water deficit affected plant growth, flowering and grain yield by $21 \%, 50 \%$ and $21 \%$ respectively (Pirdashti et al., 2004). Irrigated rice is more susceptible to drought and unable to regulate transpiration functions effectively (Vandeleur et al., 2009) and shows low tissue water potential (Kato et al., 2004) which may affect net photosynthesis rate. Even a short period of water deficit is highly sensitive to rice farming and rice productivity (O'Toole, 2004). To date, many researches have been done on reducing water use in rice cultivation but less attention was paid on suitability of implementation by the farmers. Therefore, farmers did not use some innovations on less water use in rice cultivation. In this study, we provide information on low water use in rice cultivation which could be easily adopted by the farmers. It can enhance the yield as well as the income of the farmers with less utilization of resources.

Water is the costliest input regardless of the crop. In rice, if irrigation can be provided at critical stages and instead of flooding, if the rice fields are irrigated upto $5 \mathrm{~cm}$ level at 3 DADPW then a minimum of $38 \%$ enhanced productivity can be obtained over the traditional practice where keeping the rice crop flooded till attaining reproductive stage is practised. The highest grain yield was obtained from variety Dishang (5.42 t/ha) followed by Luit (4.01 t/ha). Similarly, the maximum net return (Rs. 81240.00/ha) and B: C (2.14) were obtained from Dishang variety when irrigated upto $5 \mathrm{~cm}$ at 3 DADPW.

Now the per drop more crop policy of the government of India is going to contribute greatly towards doubling farmer's income through efficient use of every drop of water to increase use efficiency of all other inputs and also by decreasing crop production wastage on resources which will fetch higher returns in agricultural production system

\section{References}

Bouman, B.A.M., Feng, L., Tuong, T.P., Lu, G., Wang, $\mathrm{H}$ and Feng, Y. 2007. Exploring options to grow rice under water-short conditions in northern China using a modelling approach. II: Quantifying yield, water balance components, and water productivity. Agriculture of Water Management 88: 23-33

IIRI. 1972. Annual Report for 1971. Los Baños, Philippines. 238 p.

Kato, Y., Satoshi, H., Akiniko, K., Abe, J., Urasaki, K. and Yamagishi, J. 2004. Enhancing grain yield of rice (Oryza sativa L.) under upland conditions in Japan. 4th International Crop Science Congress, Brisbane, Australia.

Mohd, K., Mohd, N., Ainun, A. and Md J. S. 2015. Effect of various water regimes on rice production in lowland irrigation. Australian Journal of Crop Science. 9(2): 153-159

O'Toole, J. C. 2004. Rice and water: The final frontier. Paper presented at the 
First International Conference on Rice for the Future, Bangkok, Thailand.

Pirdashti, H., Sarvestani, Z.T., Nematzadeh, G. and Ismail, A. 2004. Study of water stress effects in different growth stages on yield and yield components of different rice (Oryza sativa L.) cultivars. The 4th International Crop Science Congress. Brisbane, Australia.

Tuong, T.P. and Bouman, B.A.M. 2003. Rice production in water scarce environments. Proceedings of the Water
Productivity Workshop, IWMI, Sri Lanka.

Vandeleur, R. K., Mayo, G., Shelden, M.C., Matthew, G. M., Kaiser, B.N. and Tyerman, S.D. 2009. The role of plasma membrane intrinsic protein aquaporins in water transport through roots: diurnal and drought stress responses reveal different strategies between isohydric and anisohydric cultivars of grapevine. Plant Physiology 149: 445-460.

\section{How to cite this article:}

Gogoi, B., R.K. Thakuria and Deka, N. 2018. Impact of Water Management on Growth and Yield of Ahu Rice Varieties of Assam, India. Int.J.Curr.Microbiol.App.Sci. 7(05): 936-941. doi: https://doi.org/10.20546/ijcmas.2018.705.115 